\title{
The Relationship between High School Students' Internet Addiction, Social Media Disorder, and Smartphone Addiction
}

\author{
Mehmet Ramazanoğlu ${ }^{1, *}$ \\ ${ }^{1}$ Department of Computer Education and Instructional Technology, Faculty of Education, Siirt University, Siirt, \\ Turkey \\ *Correspondence: Kezer Yerleşkesi Veysel Karani Mah. Üniversite Cad. No:1 56100, Department of Computer \\ Education and Instructional Technology, Faculty of Education, Siirt University, Siirt, Turkey. E-mail: \\ memedmustafa@gmail.com
}

Received: July 14, $2020 \quad$ Accepted: August 10, $2020 \quad$ Online Published: August 22, 2020

doi:10.5430/wje.v10n4p139 URL: https://doi.org/10.5430/wje.v10n4p139

\begin{abstract}
The purpose of this study is to examine the relationships between high school students' internet addiction, social media usage disorder, and smartphone addiction. The descriptive relational scanning model, one of the quantitative research methods, was used to determine this relationship. The research was carried out with 215 students who continue their education in the field of information technologies of 4 state vocational high schools in the province of Siirt in the 2018-2019 academic year. In this research, internet addiction, social media usage disorder, and smartphone addiction scales were used as data collection tools. The research data were analysed with the SPSS statistical calculation program. As a result of the research, it was observed that high school students' internet addiction, social media usage disorder, and smartphone addiction are moderate and similar in terms of gender and class levels. In the study, a positive relationship was found between high school students' internet addiction, social media usage disorder, and smartphone addiction. It was also found that all three problems were the predictors of each other. The findings were discussed with the literature along with some recommendations.
\end{abstract}

Keywords: internet addiction, social media usage disorder, smartphone addiction, technology addiction, high school students

\section{Introduction}

With the development of information technologies and the use of the internet in the 21 st century, there have been changes in behaviour, social relations, and individuals' lives. The internet provides service in many areas with its easy and cheap access. The internet has become indispensable for young people thanks to these opportunities (K1rık, 2017; Kim \& Lee, 2011). However, as well as the benefit of the internet, its damages can occur with excessive and incorrect use (Özcan \& Buzlu, 2007). Since the changes in the lives of individuals affect social relations, new social media tools have emerged (Akyazı \& Tutgun Ünal, 2013). According to the report prepared jointly by Hootsuite and Interpress titled We Are Social regarding social media in January 2020, approximately 59 percent of the world uses the internet, 49 percent uses social media, and 67 percent uses mobile. Accordingly, the number of internet users in the world is 4.54 billion, the number of social media users is 3.80 billion, and the number of mobile users is 5.19 billion.

Social media tools provide information exchange and new friendships as well as allow individuals to create groups on the internet. There are countless blogs, millions of videos, and pictures and millions of real and nicknamed accounts on the internet (Singh \& Barmola, 2015; Hargittai \& Hsieh, 2010; Ellison, Steinfield \& Lampe, 2007). Social media is a low cost, fast, and up-to-date, enabling direct communication and interaction among individuals and making social media effective and widespread (Eröz \& Doğdubay, 2012). It was pointed out that increasing communication through the internet and social media facilitates the conveyance of emotions and thoughts, therefore, strengthening the communication between users by establishing intimate relations (Öztürk \& Akgün, 2012). In addition, internet and social media tools cause addiction when used excessively (Young, 2004; Griffiths \& Szabo, 2014) and some studies suggest that uncontrolled and excessive use of social media causes addiction in some 
individuals (Griffiths \& Szabo, 2014; Griffiths, 2013 Eijnden, Lemmens, \& Valkenburg, 2016). At the same time, smartphones, which are increasing across the world, have negative effects on user relations, health and general use purposes while they also provide ease of communication for users (Park \& Lee, 2012). These effects should be regarded as addiction (Grant, Potenza, Weinstein, \& Gorelick, 2010). Smartphone addiction can be defined as not being able to be without mobile phones, checking mobile phones frequently and the overuse of mobile phones (Kuyucu, 2017).

Individuals can benefit from the internet, social media, and smartphones in their daily lives, but using these tools can be addictive. It is understood in the literature that these addictions are evaluated within the framework of behavioural addiction (Griffiths \& Szabo, 2014; Eijnden, Lemmens \& Valkenburg, 2016, Kuss \& Griffiths, 2011, Griffiths, 2013). Behavioural addiction is the inability to resist impulse and instincts. Behaviour is the feeling of increased excitement and tension before the action takes place, and the feeling of enjoyment and relaxation during the action (American Psychiatric Association, 2013). Behavioural addiction is an irresistible desire to constantly engage in an activity or behaviour, despite the negative effects on one's ability to remain mentally and/or physically healthy and functional at home and in the community (American Addiction Centres, 2019). Behavioural addiction can be defined as a desire to repeat some actions, despite the awareness that an action can have negative consequences.

Researches on internet addiction, social media addiction/disorder, and smartphone addiction have increased. In their study, Ramazanoğlu and Kıdıman (2018) investigated the internet addiction of 479 prospective teachers and the analyses were carried out on 71 prospective teachers who were dependent and on the verge of addiction. Derin and Bilge (2016) examined high school students' internet addiction. A total of 794 students attending the high school participated in the study in which it was concluded that those connecting via mobile phone and social media are more likely to have internet addiction compared to those who connect from home. It was also concluded that as the sample group's internet use time increases, internet addiction increases. Üneri and Tanıdır (2011) investigated internet addiction of high school students, concluding that the likelihood of internet addiction of male students is higher. Possible risks affecting internet addiction were determined as depression level and internet use time. Caz and Bardakçı (2019) examined the social media usage disorder of Yozgat Bozok university students. A total of 704 students (188 male students and 516 female students) participated in the study. As a result of the study, the level of social media disorder of the participants did not change according to their gender, and there was a significant difference according to the purpose of the use of social media based on departments.

Gökçearslan and Günbatar (2012) examined the secondary school students' levels of internet addiction depending on different variables. In this study which is based on the screening model, seven percent of participants were found to have internet addiction or to be on the verge of having internet addiction. It was also found that male students and students who spend more than three hours in the social network have higher levels of internet addiction. Hoşoğlu (2019) examined the mobile phone addiction of 502 volunteer high school students in his study and concluded that mobile phone addiction levels of students change significantly according to gender as an independent variable. Iş1k and Kaptangil (2018) examined smartphone addiction and social media usage of 343 university students, concluding that there was a significant relationship between smartphone addiction and social media usage. This reveals that as the time spent on social media usage increases, smartphone addiction increases.

Literature review shows that there are independent studies on the relationship between behavioural addictions (internet addiction, social media use disorder and smartphone addiction) with different variables. However, there are no studies investigating the relationship and predictive effects between them. Therefore, it is important to determine to what extent and which types of addiction these behavioural addictions are affected. It is thought that researches on the relationships between these technologies used as a distance education tool today and their effects may have vital contributions to educators in designing an effective educational environment. In addition, these researches may also play a crucial role in taking preventive measures against the risk that may occur in the use of the internet, social media and mobile environments for educational purposes. Therefore, the purpose of this study is to examine the relationships between high school students' internet addiction, social media use disorder and smartphone addiction.

The following research questions were addressed in this direction:

1. To what extent do internet addiction, social media usage disorder, and smartphone addiction occur in high school students?

2. Is there any significant difference according to gender and class level based on internet addiction, social media usage disorder, and smartphone disorder?

3. Is there any significant relationship between internet addiction, social media usage disorder, and smartphone 
disorder?

4. To what extent and how do internet addiction, social media usage disorder, and smartphone disorder predict each other?

\section{Method}

\subsection{Research Design}

In this study, a descriptive relational scanning model was used to determine the relationship between internet addictions, social media usage disorders, and smartphone addictions of students attending high school education. This model, which is one of the quantitative research methods, reveals the degree of relationship between two and more variables (Karasar, 2005).

\subsection{Sampling}

The research was carried out with students who continued their education in the $10^{\text {th }}, 11^{\text {th }}$, and $12^{\text {th }}$ grades in the field of information technologies of 4 state vocational high schools in the province of Siirt in the 2018-2019 academic year. The convenience and criterion sampling method was used for sampling. The convenience sampling method is the sampling method that is applied with the selection of the most easily accessible and practicable volunteers (Gravetter \& Forzano, 2012). Criterion sampling is a list of some criteria created by the researcher (Marshall \& Rossman, 2014). In this research, students who use the internet, use smartphones, have a social media account, and want to participate voluntarily were evaluated as the criterion. 215 scales were applied to 355 students. $132(61.4 \%)$ of the students are men and $83(38.6 \%)$ are women. 93 of the students (43.3\%) are 10th grade students, $78(36.3 \%)$ are 11th grade students and $44(20.5 \%)$ are 12th grade students. The demographic characteristics of the students participating in the research are presented in Table 1.

Table 1. The Demographic Characteristics of the Participants

\begin{tabular}{llcc}
\hline Variables & & Number of Prospective Teachers $(\mathrm{N}=215)$ & $\%$ \\
\hline Gender & Male & 132 & 61,4 \\
& Female & 83 & 38,6 \\
Department & "10th Grade" & 93 & 43,3 \\
& "11th Grade" & 78 & 36,3 \\
& "12th Grade" & 44 & 20,5 \\
\hline
\end{tabular}

\subsection{Data Collection Tools}

\subsubsection{The Internet Addiction Test (Scale):}

This scale, developed by YIBT-KF Young (1998) and converted into short-form by Pawlikowski, Altstötter-Gleich, and Brand (2013), was adapted into Turkish culture by Kutlu, Savc1, Demir, and Aysan (2016). YIBT-KF is a one-dimensional (12 items) and five-point Likert scale (never, rarely, sometimes, often, always). YIBT-KF measures internet addiction levels of both university students and adolescents. Cronbach's alpha reliability coefficient ( 0.91 for university students, 0.86 for adolescents) was found to be acceptable in the scale. In this study, Cronbach's alpha reliability coefficient was determined as 0.88 .

\subsubsection{The Social Media Disorder Scale (SMD):}

This scale was developed by Eijnden, Lemmens and Valkenburg (2016) and adapted into Turkish by Savc1, Ercengiz and Aysan (2018). Being a five-point Likert scale, it consists of one dimension and 9 items. The validity and reliability analyses of the scale were conducted with 553 adolescents with 4 different samples using social media every day and having at least one account. The construct validity of the scale was analysed by (EFA) and (CFA) analyses. Cronbach's alpha coefficient was found as 0.85 . In this study, Cronbach's alpha reliability coefficient was determined as 0.81 .

\subsubsection{The Smartphone Addiction Scale:}

This scale is a scale developed by Kwon, Kim, Cho and Yang (2013) and adapted into Turkish by Akın, Altundağ, Turan and Akın (2014). It is a five-point Likert-type measuring instrument consisting of 10 items in total. The construct validity of the scale was analysed by CFA analysis. The reliability of the scale was analysed with internal consistency while item analysis was analysed with correlation. İt is one-dimensional. Cronbach's alpha internal consistency was .88 as the reliability coefficient of the scale. Corrected item-test correlations of the scale are 
between .43 and .76 . In this study, Cronbach's alpha reliability coefficient was found as 0.89 .

\subsection{Data Collection Stage}

The research data were collected by the researcher in the schools of the participants, and the data were collected at the end of the course to avoid any disruption of the courses in the schools. The data were collected with the permission of the school administrators and all other related participants as well as with the participation of teachers. Before the data collection, the purpose of the research, the method of research, the criterion of participation, the basis of voluntary participation, the right to withdraw from the application without pressure and coercion, the expectation of sincerity, the marking of the option that suits them, the estimated application time (10-15 minutes), the privacy and declaration of use of the data obtained for research purposes were explained by the researcher. The researcher declares that this research was carried out in accordance with ethical rules and principles. Some of these principles are expressed by Smith (2003) as follows:

- Participants' rights to decline to participate and to withdraw from the research once it has started, as well as the anticipated consequences of doing so.

- Reasonably foreseeable factors that may influence their willingness to participate, such as potential risks, discomfort, or adverse effects.

- Any prospective research benefits.

- Limits of confidentiality, such as data coding, disposal, sharing and archiving, and when confidentiality must be broken.

- Incentives for participation.

- Who participants can contact with questions.

These principles were followed throughout the study.

\subsection{Data Analysis}

In order to answer the research questions, analyses were carried out with the SPSS statistical calculation program. In the research, the skewness and kurtosis values of whether the data were normally distributed or not were examined before making a comparison. Since these values ranged between -2 and +2 , they were accepted as a normal distribution (George \& Mallery, 2010). Therefore, parametric test methods were used in the analysis. In the research, to reveal the internet addiction, social media usage disorder and smartphone addiction, the mean and standard deviation were compared with the t-test for difference significance by gender, and one-way ANOVA tests for the significance of difference according to the class variable. Relationships between students' internet addiction, social media usage disorder and smartphone addiction were analysed by Pearson correlation and multiple regression. Five-point Likert type scales were used in the study. Scales (1-1,79 for $1^{\text {st }}$ degree, $1,80-2,59$ for $2^{\text {nd }}$ degree, $2,60-3,39$ for $3^{\text {rd }}$ degree, $3,40-4,19$ for $4^{\text {th }}$ degree, $4.20-5$ for $5^{\text {th }}$ degree) was interpreted with the scoring method for the degrees shown in the bracket. The correlation coefficient between the variables was interpreted as low between $0-0.29$, moderate between 0.30-0.64, high between 0.65-0.84 and very high between 0.85-1 (Ural and Kıliç, 2006).

\section{Findings}

The results of high school students' levels of internet addiction, social media usage disorder, and smartphone addiction are shown in table 2 .

Table 2. High School Students' Levels of Internet Addiction, Social Media Usage Disorder, and Smartphone Addiction

\begin{tabular}{lccc}
\hline Problems & $\mathrm{N}$ & $\mathrm{X}$ & $\mathrm{Ss}$ \\
\hline Internet addiction & 215 & 2,67 &, 943 \\
Social media usage disorder & 215 & 2,39 &, 857 \\
Smartphone disorder & 215 & 2,83 & 1,123 \\
\hline
\end{tabular}

Table 2 shows that high school students' internet addiction $(\bar{X}=2.67)$ and social media usage disorder $(\bar{X}=2.39)$ are marked as "sometimes" while the smartphone addiction $(\bar{X}=2.83)$ is marked as "indecisive".

T-test results of high school students' internet addiction, social media usage disorder, and smartphone addiction according to gender are presented in table 3 . 
Table 3. T-test Results of High School Students' Internet Addiction, Social Media Usage Disorder, and Smartphone Addiction According to Gender

\begin{tabular}{lcccccc}
\hline Problems & Gender & $\mathrm{N}$ & $\mathrm{X}$ & $\mathrm{Ss}$ & $\mathrm{t}$-test & $\mathrm{P}$ \\
\hline Internet addiction & Male & 132 & 2,64 &, 867 &, 442 &, 659 \\
& Female & 83 & 2,70 & 1,057 & &, 616 \\
Social media usage disorder & Male & 132 & 2,37 &, 789 &, 502 &, 616 \\
& Female & 83 & 2,43 &, 958 & & \\
Smartphone addiction & Male & 132 & 2,76 & 1,068 & 1,119 &, 664 \\
& Female & 83 & 2,94 & 1,205 & & \\
\hline
\end{tabular}

$* \mathrm{P}<0.05$

Table 3 shows that high school students' internet addiction $(\mathrm{t}=0.442)$, social media usage disorder $(\mathrm{t}=0.502)$, and smartphone addiction $(\mathrm{t}=1.119)$ do not differ significantly according to gender. Accordingly, it can be said that male and female students have the same level of internet addiction, social media usage disorder, and smartphone addiction.

ANOVA results of high school students' levels of internet addiction, social media usage disorder and smartphone addiction according to the class levels are presented in table 4.

Table 4. ANOVA Results of High School Students' Levels of Internet Addiction, Social Media Usage Disorder and Smartphone Addiction According to the Class Levels

\begin{tabular}{|c|c|c|c|c|c|c|}
\hline Problems & Class & $\mathrm{N}$ & $\bar{X}$ & Ss & $\mathrm{F}$ & $\mathrm{P}$ \\
\hline \multirow[t]{2}{*}{ Internet addiction } & "11th grade" & 78 & 2,62 & ,944 & & \\
\hline & "12th grade" & 44 & 2,56 &, 753 & & \\
\hline \multirow[t]{3}{*}{ Social media usage disorder } & "10th grade" & 93 & 2,50 &, 894 & 2,689 & 070 \\
\hline & "11th grade" & 78 & 2,21 &, 765 & & \\
\hline & "12th grade" & 44 & 2,47 & ,897 & & \\
\hline \multirow[t]{3}{*}{ Smartphone addiction } & "10th grade" & 93 & 2,99 & 1,207 & 1,821 &, 164 \\
\hline & "11th grade" & 78 & 2,66 & 1,025 & & \\
\hline & "12th grade" & 44 & 2,81 & 1,083 & & \\
\hline
\end{tabular}

*Intergroup degree of freedom is 2 , intragroup degree of freedom is $212,(\mathrm{P}<0.05)$

Table 4 shows that high school students' internet addiction $(\mathrm{F}=, 736)$, social media usage disorder $(\mathrm{F}=2,689)$, and smartphone addiction $(\mathrm{F}=1,821)$ do not differ significantly according to the class level. Accordingly, it can be said that male and female students have the same level of internet addiction, social media usage disorder, and smartphone addiction in all classes.

Correlation results for the relationship between high school students' internet addiction, social media usage disorder, and smartphone addiction are presented in table 5.

Table 5. Correlation Results for the Relationship between High School Students' Internet Addiction, Social Media Usage Disorder, and Smartphone Addiction

\begin{tabular}{lccc}
\hline Problems & Internet addiction & Social media usage disorder & Smartphone addiction \\
\hline Internet addiction & 1 &, $691^{* *}$ &, $698^{* *}$ \\
Social media usage disorder & & 1 &, $646^{* *}$ \\
Smartphone addiction & & & 1 \\
\hline
\end{tabular}

Table 5 shows that there is a positive high-level relationship between high school students' internet addiction and social media usage disorder $(\mathrm{r}=0.691)$. Accordingly, it can be said that as the internet addictions of high school students increase, their social media usage disorders increase. Similarly, there is a positive high-level relationship between high school students' internet addiction and smartphone addiction $(r=0.669)$. According to this, as the internet addictions of high school students increase, smartphone addictions increase. As seen in the table, there is a positive high-level relationship between high school students' social media usage disorders and smartphone addictions $(\mathrm{r}=0.646)$. Accordingly, it can be said that as the social media usage disorders of high school students increase, their smartphone addictions increase. 
Regression results regarding high school students' internet addiction, social media usage disorder, and smartphone addiction are presented in Table 6.

Table 6. Regression Results Regarding High School Students' Internet Addiction, Social Media Usage Disorder, and Smartphone Addiction

\begin{tabular}{|c|c|c|c|c|c|c|}
\hline Model 1 & $\mathrm{~B}$ & $\beta$ & $\mathrm{T}$ & $\mathrm{P}$ & $\mathrm{R}$ & $\mathrm{R} 2$ \\
\hline Stable & 556 & & 4,285 & ,000 & ,766 & ,586 \\
\hline Social media usage disorder &, 454 & ,412 & 7,116 &, 000 & & \\
\hline Smartphone addiction & ,362 & ,432 & 7,456 &, 000 & & \\
\hline Model 2 & $\mathrm{~B}$ & $\beta$ & $\mathrm{T}$ & $P$ & $\mathrm{R}$ & $\mathrm{R} 2$ \\
\hline Stable &, 568 & & 4,539 &, 000 &, 728 & ,530 \\
\hline Internet addiction & ,425 & ,468 & 7,116 &, 000 & & \\
\hline Smartphone addiction & ,244 & ,320 & 4,863 &, 000 & & \\
\hline Model 3 & $\mathrm{~B}$ & $\beta$ & $\mathrm{T}$ & $\mathrm{P}$ & $\mathrm{R}$ & $\mathrm{R} 2$ \\
\hline Stable &, 321 & & 1,906 &, 000 &, 734 & ,539 \\
\hline Internet addiction &, 573 & ,481 & 7,456 &, 000 & & \\
\hline Social media usage disorder &, 411 & ,314 & 4,863 &, 000 & & \\
\hline
\end{tabular}

$* \mathrm{P}<0.05$

Table 6 shows that, in model 1, a significant relationship was observed as a result of multiple regression analysis to reveal whether social media usage disorder and smartphone addiction predict internet addiction $(\mathrm{R}=, 766 ; \mathrm{R} 2=$, 586). Social media usage disorder and smartphone addiction explain about $59 \%$ of the total variance in internet addiction. According to this result, social media usage disorder and smartphone addiction predict internet addiction in a positive and meaningful way $(\mathrm{B}=, 454 ; \mathrm{B}=, 362)$. According to the results of the regression analysis, the regression equation for predicting internet addiction is as follows: internet addiction $=0.556+0.45+0.362$. Accordingly, it can be said that a 1-point increase in internet addiction will lead to an increase in social media usage disorder by 0.454 points and an increase in smartphone addiction by 0.362 points.

In Model 2, a significant relationship was observed as a result of multiple regression analysis to reveal whether internet addiction and smartphone addiction predict social media usage disorder $(\mathrm{R}=, 728 ; \mathrm{R} 2=, 530)$. Internet addiction and smartphone addiction explain about $53 \%$ of the total variance in social media usage disorder. According to this result, internet addiction and smartphone addiction positively predict social media usage disorder $(\mathrm{B}=, 425 ; \mathrm{B}=, 244)$. According to the results of the regression analysis, the regression equation for predicting social media usage disorder is as follows: social media use disorder $=0.568+0.425+0.244$. Accordingly, it can be said that an increase in social media usage disorder by 1 point will lead to an increase in internet addiction by 0.425 and an increase in smartphone addiction by 0.244 .

In Model 3, a significant relationship was observed as a result of multiple regression analysis to reveal whether internet addiction and social media usage disorder predict smartphone addiction $(\mathrm{R}=, 734 ; \mathrm{R} 2=, 539)$. Internet addiction and social media usage disorder explain about $54 \%$ of the total variance in smartphone addiction. According to this result, internet addiction and social media usage disorder predict smartphone addiction positively $(\mathrm{B}=, 573 ; \mathrm{B}=, 411)$. According to the results of the regression analysis, the regression equation for predicting smartphone addiction is as follows: smartphone addiction $=0.321+0.573+0.411$. Accordingly, it can be said that an increase in smartphone addiction by 1 point will lead to an increase in internet addiction by 0.573 point and an increase in social media use disorder by 0.411 points.

\section{Discussion}

In this study, the relationship between high school students' internet addiction, social media usage disorders, and smartphone addiction was investigated. In the study, it was revealed that high school students sometimes display their internet addictions and social media usage disorders and that they are indecisive in smartphone addictions. This result shows similarity with the results of related studies based on participants (Bal \& Balc1, 2020; Filiz, Erol, Dönmez, \& Kurt, 2014)

In the study, it was seen that students' internet addictions, social media usage disorders, and smartphone addictions are similar in relation to gender. This result shows parallelism with the results of several studies which revealed that there is no difference according to gender (Anlayışı \& Serin, 2019; Caz \& Bardakçı, 2019; Aktan, 2018). In the study, 
it was seen that students' internet addictions, social media usage disorders, and smartphone addictions are similar in relation to the class levels. This result is similar to the results of some studies conducted on the class level (Deniz $\&$ Gürültü, 2018; Minaz \& Çetinkaya Bozkurt, 2017).

In the findings of the study, a statistically positive, high-level, and significant relationship was found between high school students' internet addictions, social media usage disorders, and smartphone addictions. The relationship between these variables can be said to arise from technology addiction. In the studies by Işık and Kaptangil (2018), a significant relationship was found between social media usage and smartphone addiction. In the studies of Minaz and Çetinkaya Bozkurt (2017) and Öncel and Tekin (2016), it was found that the participants mostly use smartphones to log into the social network. In the studies by Filiz, Erol, and Dönmez and Kurt (2014), a positive relationship was found between the purpose of social network use and internet addiction.

It was concluded that social media usage disorder and smartphone addiction are predictors of internet addiction in a positive and meaningful way. It was determined that social media usage disorder and smartphone addiction explain approximately $59 \%$ of the total variance in internet addiction. Internet addiction and smartphone addiction turned out to be a positive and significant predictor of social media usage disorder. Internet addiction and smartphone addiction were found to explain approximately $53 \%$ of the total variance in social media usage disorder. It was concluded that internet addiction and social media usage disorder are predictors of smartphone addiction in a positive and meaningful way. Internet addiction and social media usage disorder explain about $54 \%$ of the total variance in smartphone addiction. Salehan and Negahban (2013) reported that social network use is a predictor of smartphone addiction, and smartphone addiction increases as social media usage increases (Işık \& Kaptangil, 2018). In their research, Savc1 and Aysan (2017) determined that internet, social media, digital game, and smartphone addictions are predictors of social connectedness and that smartphone addiction arises from the internet and social media use.

\section{Conclusion}

Over the last two decades, internet and smartphone use and as a result, social media usage, has increased in the wake of advances in technology. While these phenomena dominate every single individual's life all over the world, the main problem arising from the overuse of internet, smartphones and social media emerged in students' lives since a majority of students, notably students attending high schools, tend to be absorbed in using technology, which points to the internet, smartphone, and social media platforms here. This study has been designed to pay attention to such an important problem. Thus, three different scales were applied to students to achieve the goals of the study.

As a result, it was revealed that the students who participated in the study had a medium level of internet addiction, social media usage disorder, and smartphone addiction. A positive relationship was found between students' internet addiction, social media usage disorder, and smartphone addiction. It was also determined that the most powerful effect in the explanation of the internet addiction of the students is that smartphone addiction follows the social media usage disorder while in the explanation of the social media usage disorder, internet addiction is more effective than the smartphone addiction, and internet addiction is more effective than the social media usage disorder in the explanation of the smartphone addiction. Accordingly, in behavioural addictions of high school students, internet addiction, social media usage disorder, and smartphone addiction are effective, respectively.

In light of the results obtained in the study, trainings on students' conscious internet, social media and smartphone use can be given and studies can be conducted on the solution of the negative effects of these platforms in education.

\section{References}

Akın, A., Altundağ, Y., Turan, M. E., \& Akın, U. (2014). The validity and reliability of the Turkish version of the Smart Phone Addiction Scale-Short Form for Adolescent. Procedia-Social and Behavioral Sciences, 152, 74-77. https://doi.org/10.1016/j.sbspro.2014.09.157

Aktan, E. (2018). Assessment of social media addiction levels of university students by numerous variables. Erciyes Iletişim Dergisi, 5(4), 405-421. https://doi.org/10.17680/erciyesiletisim.379886

Akyazı, E., \& Tutgun Ünal, A. (2013). Purpose, adoption and level of loneliness relation and the use of social networks: a study on undergraduate communication students. Global Media Journal Turkish Edition, 3(6), 1-24. https://globalmediajournaltr.yeditepe.edu.tr/bahar-2013-sayisi-spring-2013-issue

American Addiction Centers (2019). Behavioral Addictions. Retrieved from https://americanaddictioncenters.org/behavioral-addictions 
American Psychiatric Association (2013). Diagnostic and statistical manual of mental disorders. 4. Washington, DC: American Psychiatric Publishing, Inc; 2000. Text revision (DSM-5-TM). https://doi.org/10.1176/appi.books.9780890425596

Anlayışl1, C., \& Bulut Serin, N. (2019). A study on internet addiction and depression among high school students due to gender, academic success and internet usage duration. Folklor/Edebiyat, 25(97), 730-743. http://dx.doi.org/10.22559/folklor.978

Bal, E., \& Balcı, Ş. (2020). Smartphone addiction: a study on efficacy of personality traits and usage patterns. Journal of Erciyes Communication, 7(1), 369-394. https://doi.org/10.17680/erciyesiletisim.654569

Caz, Ç., \& Bardakçı, S. (2019). Social media disorder: a research on university students. OPUS-Uluslararası International Journal of Society Researches, 10(17), 1100-1124. https://doi.org/10.26466/opus.521522

Deniz, L., \& Gürültü, E. (2018). High school students' social media addiction. Kastamonu Education Journal, 26(2), 355-367. https://doi.org/10.24106/kefdergi.389780

Derin, S., \& Bilge, F. (2016). Internet addiction and the level of subjective well-being in adolescents. Türk Psikolojik Danışma ve Rehberlik Dergisi, 6(46), 35-51. https://dergipark.org.tr/tr/pub/tpdrd/issue/42744/515910

Ellison, N. B., Steinfield, C., \& Lampe, C. (2007). The benefits of Facebook "Friends:" social capital and college students' use of online social network sites. Journal of Computer Mediated Communication, 12(4), 1143-1168. https://doi.org/10.1111/j.1083-6101.2007.00367.x

Eröz, S. Sü \& Doğdubay, M. (2012). The role of social media in the choice of tourist products and ethical relationship. Dokuz Eylül Üniversitesi İktisadi ve İdari Bilimler Fakültesi Dergisi, 27(1), 33-157.

Filiz, O., Erol, O., Dönmez, F., \& Kurt, A. (2014). Examination of the Correlation between Aims of Social Network Sites Usage and Internet Addiction of Computer and Instructional Technology Department Students. Journal of Instructional Technologies \& Teacher Education, 3(2), 17-28.

George, D., \& Mallery, M. (2010). SPSS for windows step by step: a simple guide and reference, 17.0 update (10th ed.). Boston: Allyn \& Bacon.

Gökçearslan, Ş., \& Günbatar, M. S. (2012). Internet addiction in high school students. Eğitim Teknolojisi: Kuram ve Uygulama (ETKU), 2(2), 10-24.

Grant, J. E., Potenza, M. N., Weinstein, A., \& Gorelick, D. A. (2010). Introduction to behavioral addictions. The American Journal of Drug and Alcohol Abuse, 36(5), 233-241. https://doi.org/10.3109/00952990.2010.491884

Gravetter, F. J., \& Forzano, L. B. (2012). Research Methods for the Behavioral Sciences (4th ed.). Belmont, CA: Wadsworth.

Griffiths, M. D. (2013). Social networking addiction: Emerging themes and issues. Journal of Addiction Research \& Therapy, 4, 118. https://doi.org/10.4172/2155-6105.1000e118

Griffiths, M. D., \& Szabo, A. (2014). Is excessive online usage a function of medium or activity? An empirical pilot study. Journal of behavioral addictions, 3(1), 74-77. https://doi.org/10.1556/JBA.2.2013.016

Hargittai, E., \& Hsieh, Y.-L. P. (2010). Predictors and consequences of differentiated practices on Social Network Sites. Information, Communication \& Society, 13(4), 515-536. https://doi.org/10.1080/13691181003639866

Hoşoğlu, R. (2019). Investigating mobile phone addiction in high school students. Addicta: The Turkish Journal on Addictions, 6, 51-68. https://doi.org/10.15805/addicta.2019.6.1.0024

Işık, M., \& Kaptangil, İ. (2018). The relation of smart phone addiction to social media usage and five factor personality trait: A research on university students. Journal of the Human and Social Science Researches, 7(2), 695-717.

Karasar, N. (2005). Bilimsel araştırma yöntemi. Nobel Yayınları, Ankara.

Kim, J., \& Lee, J. R. (2011). The facebook paths to happiness: Effects of the number of facebook friends and self-presentation on subjective well-being. Cyberpsychology, Behavior and Social Networking, 14(6), 359-364. https://doi.org/10.1089/cyber.2010.0374

Kırık, A. (2017). Yeni Medya Aracılığıyla Değişen İletişim Süreci: Sosyal Paylaşım Ağlarında Gençlerin Konumu. Gümüşhane Üniversitesi Iletişim Fakültesi Elektronik Dergisi, 5(1), 230-261. https://doi.org/10.19145/gumuscomm.300815 
Kuss, D. J., \& Griffiths, M. D. (2011). Online social networking and addiction -a review of the psychological literature. Int J Environ Res Public Health, 8(9), 3528-3552. https://doi.org/10.3390/ijerph8093528

Kutlu, M., Savc1, M., Demir, Y., \& Aysan, F. (2016). Turkish adaptation of Young's Internet Addiction Test-Short Form: a reliability and validity study on university students and adolescents. Anatolian Journal of Psychiatry, 17(Suppl.1), 69-76.

Kuyucu, M. (2017). Use of smart phone and problematic of smart phone addiction in young people: "smart phone (colic)" university youth. Global Media Journal TR Edition, 7(14), 328-359.

Kwon, M., Kim, D. J., Cho, H., \& Yang, S. (2013). The Smartphone Addiction: Development and validation of a short version for Adolescents (SAS-SV). PloS one, 8(12), e83558. https://doi.org/10.1371/journal.pone.0083558

Marshall, C., \& Rossman, G. B. (2014). Designing qualitative research. New York: Sage.

Minaz, A., \& Çetinkaya Bozkurt, Ö. (2017). Investigation of university students smartphone addiction levels and usage purposes in terms of different variables. Mehmet Akif Ersoy Üniversitesi Sosyal Bilimler Enstitüsü Dergisi, 9(21), 268-286. https://doi.org/10.20875/makusobed.306903

Öncel, M., \& Tekin, A. (2016). Investigation of secondary school students' facebook addiction levels and usage purposes in terms of different variables. Adlyaman University Journal of Educational Sciences, 6(1), 179-197. https://doi.org/10.17984/adyuebd.36186

Özcan, N. K., \& Buzlu, S. (2007). Internet use and its relation with the psychosocial situation for a sample of university students. Cyberpsychology \& Behavior, 10(6), 767-772. https://doi.org/10.1089/cpb.2007.9953

Öztürk, M., \& Akgün, Ö. E. (2012). Unıversity students' purposes in using social networking sites, and their opinions on using these sites in education. Sakarya University Journal of Education, 2(3), $49-67$.

Park, N., \& Lee, H. (2012). Social implications of smartphone use: Korean college students' smartphone use and psychological well-being. Cyberpsychology, Behavior, and Social Networking, 15, 491-497. https://doi.org/10.1089/cyber.2011.0580

Ramazanoğlu, M., \& Kıdıman, E. (2018). An analysis of internet addiction of the teacher candidates who are in different branches. Journal of Social and Humanities Sciences Research, 5(24), 1515-1526. http://dx.doi.org/10.26450/jshsr.520

Salehan, M., \& Negahban, A. (2013). Social Networking on Smartphones: When Mobile Phones Become Addictive. Computers in Human Behavior, 29(6), 2632-2639. https://doi.org/10.1016/j.chb.2013.07.003

Savc1, M., \& Aysan, F. (2017). Technological addictions and social connectedness: predictor effect of internet addiction, social media addiction, digital game addiction and smartphone addiction on social connectedness. Dusunen Adam the Journal of Psychiatry and Neurological Sciences, 30(3), 202-216. https://doi.org/10.5350/DAJPN2017300304

Savc1, M., Ercengiz, M., \& Aysan, F. (2018). Turkish Adaptation of the Social Media Disorder Scale in Adolescents. Arch Neuropsychiatry, 55, 248-255. https://doi.org/10.5152/npa.2017.19285

Singh, N., \& Barmola, K. C. (2015). Internet Addiction, mental health and academic performance of school students/adolescents. The International Journal of Indian Psychology, 2(3), 98-108.

Smith, D. (2003). Cover story: Five principles for research ethics "Cover your bases with these ethical strategies." American Psychological Association, 34(1), 56.

Üneri, Ö. Ş., \& Tanıdır, C. (2011). Evaluation of internet addiction in a group of high school students: a cross-sectional study. Dusunen Adam the Journal of Psychiatry and Neurological Sciences, 24(4), 265-272.

Ural, A., \& Kılıç, O. (2006). Bilimsel araştırma süreci ve spss ile veri analizi (spss 10.0012 .0 for windows). Detay Yayıncılık, Ankara.

Van den Eijnden RJJM, Lemmens J. S., \& Valkenburg, P. M. (2016). The social media disorder scale. Computers in Human Behavior, 61, 478-487. https://doi.org/10.1016/j.chb.2016.03.038

Young, K. S. (1998). Internet addiction the emergence of a new clinical disorder. CyberPsychology \& Behavior, 1(3), 237-244. https://doi.org/10.1089/cpb.1998.1.237

Young, K. S. (2004). Internet addiction: A new clinical phenomenon and its consequences. American Behavioral Scientist, 48(4), 402-415. https://doi.org/10.1177/0002764204270278 


\section{Copyrights}

Copyright for this article is retained by the author(s), with first publication rights granted to the journal.

This is an open-access article distributed under the terms and conditions of the Creative Commons Attribution license (http://creativecommons.org/licenses/by/4.0/). 